\title{
Bazı Kimya Konularındaki Alternatif Kavramların Tanılayıcı Dallanmış Ağaç Tekniği Kullanarak Belirlenmesi*
}

\section{Identifying Alternative Concepts In Some Chemistry Topics Using The Diagnostic Branched Tree Technique}

\author{
Gürkan GEÇGEL**, Ali Rıza ŞEKERCI****
}

\begin{abstract}
Öz: Bu çalışmada, geleneksel ölçme ve değerlendirme araçlarına alternatif olan Tanılayıcı Dallanmış Ağaç (TDA) tekniği kullanılarak geliştirilen kavram testi ile öğrencilerin bazı kimya konularında alternatif kavramlara sahip olup olmadıklarını belirlemektir. TDA, geleneksel ölçme ve değerlendirme araçlarından yapısı ve amacının farklı olmasıyla dikkat çekmektedir. Çalışma tarama yöntemi ile yürütülmüştür. Çalışma Dumlupınar Üniversitesi Eğitim Fakültesi Sınıf öğretmenliği Anabilim Dalıve Fen Bilgisi Eğitimi Anabilim Dallarında öğrenim gören 222 öğretmen adayı ile gönüllülük esasına dayalı olarak gerçekleştirilmiştir. Çalışmadan elde edilen verilerin analizinde betimsel istatistiki yöntem kullanılmıştır. TDA tekniği ile hazırlanan kavram testinin analizinden elde edilen bulgular neticesinde öğretmen adaylarının madde ve özellikleri, elementler, bileşikler, çözeltiler ve koligatif özellikler, metaller, fiziksel ve kimyasal değişimler, asitler ve bazlar, kimyasal bağlar, ısı ve sıcaklık kimya konuları ile ilgili alanyazında vurgulanan alternatif kavramlara sahip oldukları ortaya konmuştur.
\end{abstract}

Anahtar Kelimeler: Tanılayıcı dallanmış ağaç, alternatif kavram, kavram testi

\begin{abstract}
This study aimed to identify whether students possess alternative concepts in certain chemistry topics, through making use of a concept test which was developed using the Diagnostic Branched Tree (DBT) technique which is an alternative to traditional assessment and evaluation instruments. DBT differs from traditional assessment and evaluation instruments in terms of its structure and goal. The study adopts a survey method. The study was conducted with 222 teacher candidates who were studying at Dumlupınar University, Education Faculty, Primary School Teaching and Science Teaching Departments and who participated in the study on a volunteer basis. The study data were analyzed using descriptive statistics. According to the analysis results of the concept test which was developed through the DBT technique, teacher candidates were found to possess alternative concepts emphasized in related chemistry literature such as matter and its features, elements, compounds, solutions and colligative features, metals, physical and chemical changes, acids and bases, heat and temperature issues.

Keywords: Chemistry, diagnostic branched tree, alternative concept, concept test
\end{abstract}

\section{Giriş}

Fen eğitimi içindeki kimya kavramlarının bireyler tarafından gündelik yaşamda fazlaca karşılaştıkları fen olayları ile ilişkilendirmeleri önemlidir (Pınarbaşı, Doymuş, Canpolat ve Bayrakçeken, 1998; Yadigaroğlu ve Demircioğlu, 2012). Bu kavramların kalıcı olması yaşantımızdaki olayların doğru anlaşılması ile ilgilidir (Özmen, 2003). Bazen bireylerin edindiği yanlış bilgi ve gözlemler okul çağında alternatif kavram olarak karşımıza çıkmaktadır. Öğrenciler, kendi gözlemlerini anlamlı ve uyumlu olacak bir şekilde bilimsel doğru kabul ederek alternatif kavramları zihinlerinde oluştururlar. Alternatif kavramlar öğrencilerin sonraki öğrenmelerinde de etkin olur ve yeni kavramların doğru anlaşılmamasını sağlar (Canpolat ve Pınarbaş1, 2011). Hatta bu alternatif kavramlar eğitimi çok ciddi bir şekilde engelleyebilir (Yağbasan ve Gülçiçek, 2003). Söz konusu durum fen bilimleri içerisinde yer alan kimya konuları içinde geçerlidir. Öğrenciler kimya konularında yer alan temel kavramları yanlış kavramsallaştırırlarsa, daha üst düzey kavramların doğru bir şekilde oluşturulmasında ve önceki

* Bu çalışma, birinci yazarın ikinci yazar danışmanlığında hazırlandığı yüksek lisans tezinden üretilmiştir.

***̈zel Kütahya Temel Lisesi, Kütahya-Türkiye, e-posta: gurkangecgel@gmail.com

****Dr. Öğretim Üyesi, Dumlupınar Üniversitesi, Eğitim Fakültesi, Kütahya-Türkiye, e-posta: sekerciar@gmail.com 
bilgiler ile yeni bilgiler arasında ilişki kurmada güçlükler yaşamaktadırlar (Canpolat ve Pınarbaş1, 2012). Bununla birlikte öğrenciler öğrenme ortamında önceki yaşantılarında tecrübe ettiği alternatif kavramları yeni konularına aktarırlar. Yeni öğrendikleri kavramları mevcut alternatif kavramla ilişkilendirmekte zorlanırlar. Bundan dolayı öğrenme süreci aksayabilir, dahası yeni alternatif kavramlar açığa çıkabilir (Canpolat ve Pınarbaşı, 2011). Öğrencilerde var olan ya da var olduğu düşünülen alternatif kavramları tespit etmek ve sonrasında giderme çalışmaları yapmak bu sebeplerden dolayı çok önemlidir.

Araştırmacılar kimyada var olan alternatif kavramları farklı ölçme araçları kullanarak ortaya çıkarmışlardır. Alanyazında kimyada var olan alternatif kavramların tespiti için açık uçlu sorular (ör. Cartrette ve Mayo, 2011; Dönmez-Usta ve Ayas, 2010; Kolomuç ve Tekin, 2011; Pınarbaşı, Canpolat ve Sözbilir, 2009; Sekerci ve Canpolat, 2014), çoktan seçmeli sorular (ör. Erdemir, Geban ve Uzuntiryaki, 2000; Herrmann-Abell ve DeBoer, 2011; Sekerci ve Canpolat, 2014), iki aşamalı teşhis edici test (ör. Taber ve Tan, 2011; Tüysüz, 2009; Voska ve Heikkinen, 2000), üç aşamalı teşhis edici test (ör. Çetin-Dindar ve Geban, 2011; Kirbulut ve Geban, 2014) ve tanılayıcı dallanmış ağaç tekniği (Sekerci, 2015) ile hazırlanan testler kullanılmıştır. Kolomuç ve Tekin (2011) 70 kimya ögrretmenine beş açık uçlu soru sorarak kimyasal reaksiyon hızı konusundaki öğretmenlerin yanlış kavramlarını tespit etmiştir. Başka bir çalışmada sınıf öğretmenliği ögrencilerine beş açık uçlu sorudan oluşan bir test yapılmış ve mumun yanmasıyla ilgili alternatif kavramların varlığı açığa çıkarımıştır (Pınarbaşı ve diğerleri, 2009). Çoktan seçmeli soruların kullanıldığı bir çalışmada öğretmen adaylarına çoktan seçmeli kimyasal denge kavramıyla ilgili başarı testi uygulanmış ve birçok öğretmen adayının kimyasal denge ve reaksiyon hızı kavramları hakkında alternatif kavramlara sahip oldukları belirlenmiştir (Erdemir ve diğerleri, 2000). Mavi (2008) ise çoktan seçmeli sorulardan oluşan testleri kullanarak ögrencilerin radyasyon konusu ile ilgili alternatif kavramlara sahip olup olmadıklarını tespit etmiştir. Herrmann-Abell ve DeBoer (2011) ise enerji dönüşümleri ile ilgili çoktan seçmeli sorularla öğrencilerin bu konudaki alternatif kavramları incelemiştir. İki aşamalı teşhis edici testlerde ise öğrencilerin kimyasal denge problemlerini çözerken sayısal kimya anlayışlarını ortaya çıkarmak için bu test kullanılmış ve kimyasal denge ile ilgili yaygın yanlış anlayışların olduğu vurgulanmıştır (Voska ve Heikkinen, 2000). Başka bir çalışmada Tüysüz (2009) maddelerin ayrıştırılması konusunda öğrencilerde ki alternatif kavramların açığa çıkarılabilmesi için öğretmenlerin iki aşamalı testin kullanması gerektiğini belirtmiştir. Çetin-Dindar ve Geban (2011) üç aşamalı tanı testi ile asit-baz kavramlarında öğrencilerin anlayışlarını değerlendirmiştir. Diğer bir çalışmada lise öğrencilerine maddenin hallerine yönelik 19 soruluk üç aşamalı tanı testi sayesinde alternatif kavramlar tespit edilmiştir (Kirbulut ve Geban, 2014). Sekerci (2015) kimya konularında lise öğrencilerinin alternatif kavramlara sahip olup olmadıklarını alternatif ölçme ve değerlendirme tekniklerinde biri olan tanılayıcı dallanmış ağaç (TDA) tekniği kullanılarak ortaya çıkarmıştır.

TDA, anlamlı öğrenmenin olup olmadığı, öğrencinin zihnindeki yanlış anlaşılan alternatif kavramları ve eksik öğrenmenin nedenlerini ortaya çıkaran bir teşhis aracıdır (Johnstone, McAlpine ve MacGuire, 1986). Bahar (2001) TDA'nın öğrencide var olan zihninde yer etmiş yanlış bağlantıları, yanlış stratejileri ve neticede yanlış olan bilgiyi ortaya çıkartan, etkili öğrenme ve öğretmede önemli bir unsur olduğunu vurgulamaktadır. Ayrıca TDA, öğrencilerin zihindeki bilgi örüntülerini açığa çıkaran ve alternatif kavramlarını belirlemeyi amaçlayan tekniktir (Kocaarslan, 2012; Şahin ve Çepni, 2011). Bunun yanı sıra TDA'nın öğrencilerin hem kendi kendilerini değerlendirmelerinde büyük bir rol oynamakta hem de öğretmenlerin öğrencilerin yanlışlarını fark edip düzeltmelerine yardımcı olmalarında etkili bir teknik olduğu vurgulanmaktadır (Gecgel ve Sekerci, 2015; Karaoğlan ve Çatak, 2005). Buna rağmen Çelen (2014), tekniğin doğru-yanlış maddelerin kullanılmasının teşhis zayıflı̆̆ına yol açtı̆̆ını ve tekniğin adının tanılayıcı olmasının şekilsellikten öteye gidemediğini ifade etmiştir. $\mathrm{Bu}$ çalışmanın amacı, öğretmen adaylarının bazı kimya konularında (Kimyasal türler arası etkileşim: fiziksel ve kimyasal değişimler, kimyasal bağlar: molekül içi ve moleküller arası bağlar, kimya bilimi: elementler ve bileşikler, kimyasal madde kullanımı, çözeltiler ve fiziksel özellikleri, asitler ve bazlar, sıvıların özellikleri ve buharlaşma, gazlar ve çözünürlük, karışımlar 
ve ayırma yöntemleri, 1sı ve sicaklık) alternatif kavramlara sahip olup olmadıklarını TDA tekniği ile hazırlanana kavram testiyle belirlemektir. Çalışmada Fen Bilgisi ve Sınıf öğretmeni adaylarının bazı kimya konularında sahip oldukları alternatif kavramlar nelerdir? sorusuna yanıt aranmıştır.

\section{Yöntem}

Araştırmada, tarama yöntemi kullanılmıştır. Bu yöntem araştırmalar, problemi veya olayı kapsayabildiğince tam ve dikkatli tanımlar. Eğitimde bir araştırmada en çok tercih edilen yöntemdir (Büyüköztürk, Çakmak, Akgün, Karadeniz ve Demirel, 2012; McMillan ve Schumacher, 2014).

\section{Çalışma grubu}

Çalışma grubu 2013-2014 eğitim-öğretim yılı Dumlupınar Üniversitesi Eğitim Fakültesi Sınıf Öğretmenliği anabilim dalı ve Fen Bilgisi Öğretmenliği anabilim dalında öğrenim gören gönüllülük esasına dayalı 161'i kı, 61'i erkek toplam 222 öğretmen adayı oluşturmaktadır. Araştırma kapsamında çalışma grubunun anabilim dallarına (programlara) ve cinsiyete göre dağılımı Tablo 1'de yer almaktadır.

Tablo 1.

Uygulamaya Katılan Öğretmen Adaylarının Dağılımı

\begin{tabular}{|c|c|c|c|c|}
\hline Programı & & $\begin{array}{c}\mathrm{K} 1 \mathrm{z} \\
(\mathrm{n})\end{array}$ & $\begin{array}{c}\text { Erkek } \\
\text { (n) }\end{array}$ & $\begin{array}{c}\text { Toplam } \\
\text { (n) }\end{array}$ \\
\hline Sınıf Öğretmenliği A.B.D. & & 73 & 25 & 98 \\
\hline \multirow[t]{2}{*}{ Fen Bilgisi Öğretmenliği A.B.D. } & & 88 & 36 & 124 \\
\hline & Toplam & 161 & 61 & 222 \\
\hline
\end{tabular}

Çalışma grubu seçkisiz olmayan örnekleme yöntemlerinden uygun örnekleme (convenience sampling) yöntemi ile belirlenmiştir (Büyüköztürk ve diğerleri, 2012; McMillan ve Schumacher, 2014). Uygun örnekleme yönteminde zaman, para ve işgücü kaybını önlenmesi amaçlanmaktadır (Büyüköztürk ve diğerleri, 2012). McMillan ve Schumacher (2014) uygun örnekleme yönteminin kullanılmasındaki en önemli noktanın örneklem seçiminin kolay ulaşılabilir, yapılacak çalışmaya uygun ve elverişli olmasını ifade etmişlerdir. Ancak uygun örnekleme yönteminin dezavantajı olarak araştırmadan elde edilen sonuçların evrene genellenememesi olarak vurgulanmıştır (McMillan ve Schumacher, 2014).

\section{Veri toplama aracı}

Çalışmada araştırmacılar tarafından geliştirilen 22 maddelik tanılayıcı dallanmış ağaç tekniği ile hazırlanan kavram testi kullanılmıştır (Gecgel ve Sekerci, 2015). Kavram testinin ortalama güçlük indeks değeri 0.55 ve ortalama madde ayırt edicilik değeri 0.35 olarak hesaplanmıştır. İstatistik programı kullanılarak kavram testinden elde edilen ölçümün KR-20 güvenirlik katsayıs1 0.75 olarak hesaplanmıştır. Bu sonuçla testin yeterli bir güvenirliğe sahip olduğu söylenebilir. Güvenirlik katsayısının 0.70 ve daha yüksek olması ölçümün güvenirliği için genel olarak yeterli görülmektedir (Field, 2013; Fraeklen, Wallen, ve Hyun, 2011; Van Blerkom, 2009). Ayrıca ölçümün güvenirliği için iki yarıya bölme yöntemi de kullanılmıştır. Testin iki yarısı arasındaki tutarlılık yarıya bölme metoduyla bulunan güvenirlik katsayısıyla ilişkilidir. $\mathrm{Bu}$ katsayı, yüksek çıkmış ise testin cevaplanmasının rastgele olmadığı, testin homojen yani aynı davranışları ölçtüğü, testin random hatalardan arınık ve iki yarının eşdeğer olduğu anlamına gelir (Ergin, 1995; Field, 2013). İstatistik programı kullanılarak kavram testinden elde edilen ölçümün Spearman-Brown güvenirlik katsayısı 0.74 olarak hesaplanmışır (Gecgel ve Sekerci, 2015). Bu değer göre teste ait ölçümün yeterli bir güvenirliğe sahip olduğu söylenebilir. Şekil 1 'de TDA tekniği ile hazırlanan kavram testine ait örnek bir madde verilmiştir. 


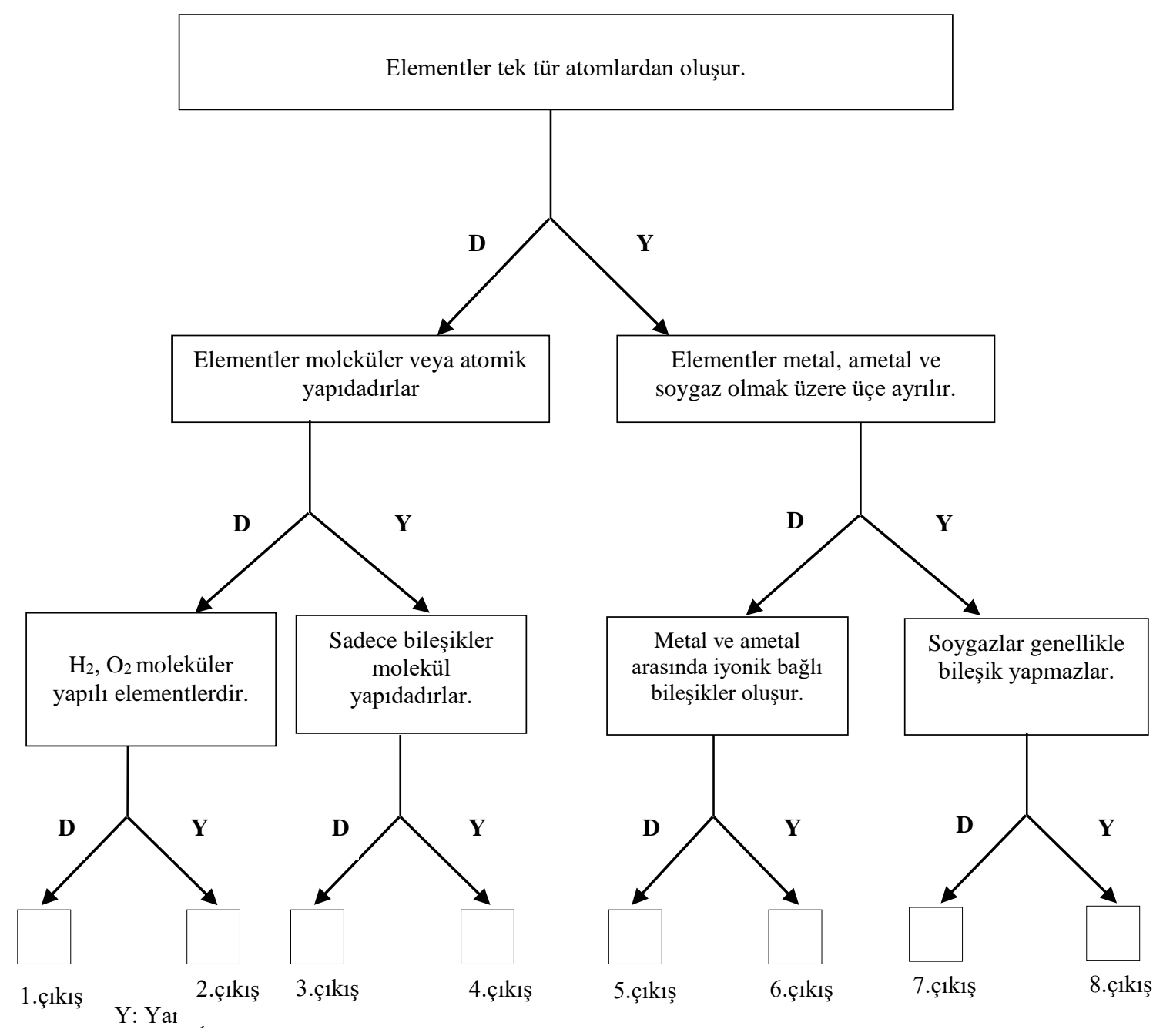

Şekil 1. Elementler Konusunu İçeren Tanılayıcı Dallanmış Ağaç Örneği

\section{İşlem}

TDA tekniği ile hazırlanan kavram testi Dumlupınar Üniversitesi Eğitim Fakültesi Sınıf öğretmenliği anabilim dalı ve Fen Bilgisi anabilim dalı öğrenim gören gönüllülük esasına göre çalışmaya katılan 222 öğretmen adayına uygulanmıştır. Araştırma verilerinin toplanmasında kullanılan kavram testi öğretmen adaylarına dağıtılmış ve araştırmacılar tarafindan öğretmen adaylarına araştırmanın konusu, amacı ve içeriği hakkında bilgi verilmiştir. Kavram testinin uygulanması ve toplanması sürecinde gizlilik ilkesine kesinlikle uyulmuştur. Kavram testinin uygulanması 20-25 dakikalık bir süre içerisinde gerçekleşmiştir.

\section{Verilerin analizi}

Tanılayıcı dallanmış ağaç tekniği ile geliştirilen kavram testinin verilerinin analizinde SPSS 21 paket programı kullanılmıştır. Öğretmen adaylarının kavram testindeki her bir maddeye vermiş oldukları cevaplar incelenmiş ve sahip oldukları alternatif kavramlar frekans ve yüzde değerleri tablolar halinde sunulmuştur.

\section{Bulgular}

TDA tekniği ile hazırlanan kavram testindeki maddelerin öğretmen adayları tarafindan işaretlenen her bir çıkış incelenmiş ve sahip oldukları alternatif kavramlar açığa çıkarılmıştır. 
TDA Tekniği ile Elde Edilen Alternatif Kavramlar

Maddenin fiziksel ve kimyasal değişim konusuna yönelik öğretmen adaylarında var olan alternatif kavramlar aşağıdaki Tablo 2'de verilmiştir.

Tablo 2.

Kimyasal Türler Arası Etkileşim: Fiziksel ve Kimyasal Değişimler Konusu ile ilgili Alternatif Kavramların Dağılımı

\begin{tabular}{|c|c|c|c|}
\hline Konu & Alternatif Kavramlar & $\mathrm{f}$ & $\%$ \\
\hline \multirow{5}{*}{ 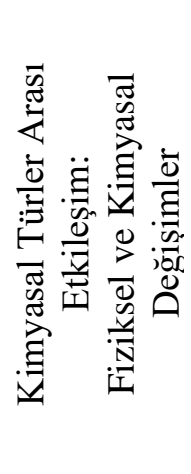 } & Yoğunluk maddenin fiziksel özelliği değildir. & 108 & $48.6^{*}$ \\
\hline & Kimyasal değişime uğrayan madde, fiziksel değişim & 36 & 16.2 \\
\hline & $\begin{array}{l}\text { Domatesin zamanla şekli, kokusu, tadı değişir ve } \\
\text { olgunlaşır. Bu olay kimyasal değişim değildir. }\end{array}$ & 33 & 14.9 \\
\hline & Kar yağarken ortama 1s1 vermez. & 27 & 12.2 \\
\hline & $\begin{array}{l}\text { Domatesin zamanla şekli, kokusu, tadı değişir ve } \\
\text { olgunlaşır. Dış görünüşü değiştiği için sadece fiziksel } \\
\text { değişimdir. }\end{array}$ & 27 & 12.2 \\
\hline
\end{tabular}

Not: Bu ve diğer tablolarda \%10’un üzerindeki ifadeler alternatif kavram olarak alınmıştır.

Tablo 2 incelendiğinde öğretmen adaylarının yaklaşık yarısında (\%48.6'sında), yoğunluğun maddenin fiziksel özelliği olmadığı \%16.2'sinde kimyasal değişime uğrayan maddenin fiziksel değişim geçirmediği şeklinde alternatif kavramlara sahip oldukları tespit edilmiştir.

Kimyasal bağlar konusuna yönelik öğretmen adaylarının \%50.9'u moleküller arası bağın molekül içi bağ olduğunu, apolar kovalent bağ aynı tür ametaller arasında olmadığını (\%20.3'ü) ve \%17.2'si kovalent bağın ise ametal atomlar arasında olmadığı şeklinde alternatif kavramlara sahip oldukları açığa çıkmıştır (Tablo 3).

Tablo 3.

Kimyasal Bağlar: Molekül İçi ve Moleküller Arası Bağlar Konusu ile ilgili Alternatif Kavramların Dağılımı

\begin{tabular}{|c|c|c|c|}
\hline Konu & Alternatif Kavramlar & $\mathrm{f}$ & $\%$ \\
\hline 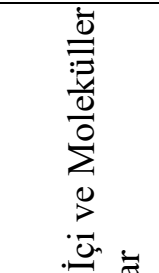 & $\begin{array}{l}\text { Şekildeki } 2 \text { nolu bağ (moleküller arası } \\
\text { bağ) Molekül içi bağa örnektir. }\end{array}$ & 113 & 50.9 \\
\hline $\bar{\square}$ & Apolar kovalent bağ aynı tür ametaller arasında değildir. & 45 & 20.3 \\
\hline$\sum_{i=\frac{\pi}{2}}^{\infty}$ & Kovalent bağ ametal atomları arasında oluşmaz. & 38 & 17.2 \\
\hline$\frac{\pi}{100}$ & Bağ oluşumu sırasında minimum enerjiye eğilim yoktur. & 36 & 16.2 \\
\hline$\frac{\infty}{\pi}$ & $\begin{array}{l}\text { Bağ oluşumundan sonra atomun yapısı kararlı hale } \\
\text { gelmez. }\end{array}$ & 29 & 13.1 \\
\hline$\ddot{g}$ & Bağlar atomları bir arada tutan çekim kuvveti değildir. & 24 & 10.9 \\
\hline
\end{tabular}

Not: Tabloda \%10’un üzerindeki alternatif kavramlar verilmiştir. 
Elementler ve bileşikler konusuna yönelik öğretmen adaylarının sahip oldukları alternatif kavramlar incelendiğinde ortaya çıan bulgular Tablo 4'de gösterilmiştir.

Tablo 4.

Elementler ve Bileşikler Konusu İle İlgili Alternatif Kavramların Dağılımı

\begin{tabular}{|c|c|c|c|}
\hline Konu & Alternatif Kavramlar & $\mathrm{f}$ & $\%$ \\
\hline \multirow{10}{*}{ 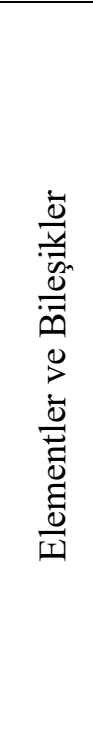 } & $\begin{array}{l}\text { İyonik bağ sadece } \\
\text { paylaşımıyla oluşur. }\end{array}$ & 79 & 35.7 \\
\hline & İyonik bağlı bileşikler katı halde elektriği iletir. & 55 & 24.8 \\
\hline & $\begin{array}{l}\mathrm{O}_{2} \text { ve } \mathrm{CO}_{2} \text { gazları ametaller arasında elektron ortaklaşmasıyla } \\
\text { oluşmamaktadır. }\end{array}$ & 53 & 24.0 \\
\hline & Elementler, moleküler veya atomik yapıda değildirler. & 45 & 20.3 \\
\hline & $\begin{array}{l}\text { Ametaller periyodik cetvelin (hidrojen hariç) sağ tarafında } \\
\text { değildir. }\end{array}$ & 40 & 18.1 \\
\hline & Elementler tek tür atomlardan oluşmaz. & 39 & 17.7 \\
\hline & $\begin{array}{l}\mathrm{CaBr}_{2} \text { kalsiyum di bromür olarak adlandırılır. } \\
\text { Ametaller tel ve levha haline gelir. }\end{array}$ & $\begin{array}{l}35 \\
35\end{array}$ & $\begin{array}{l}15.8 \\
15.8\end{array}$ \\
\hline & Sadece bileşikler molekül yapıdadırlar. & 33 & 14.9 \\
\hline & $\begin{array}{l}\text { İyonik bağlı bileşik hal değiştirince moleküller arası bağ } 1 \\
\text { kopmaz }\end{array}$ & 30 & 13.6 \\
\hline & Ametallerin yüzeyleri mat değildir. & 26 & 11.8 \\
\hline
\end{tabular}

Tablo 4'e göre öğretmenler adaylarının \%35.7'sinde "İyonik bağın sadece ametaller arasında elektronların paylaşımıyla oluşur.", \%24.8'inde "İyonik bağlı bileşikler katı halde elektriği iletir.", \%24.0'sında " $\mathrm{O}_{2}$ ve $\mathrm{CO}_{2}$ gazları ametaller arasında elektron ortaklaşmasıyla oluşmamaktadır.", \%20.3'ünde "Element, moleküler veya atomik yapıda değildir.”, \%18.1'inde "Ametaller periyodik cetvelin (hidrojen hariç) sağ tarafinda değildir." şeklinde ki ifadelerle bilimsel olarak yanlış cevap verdikleri görülmektedir. Diğer bir ifadeyle öğretmen adaylarının elementler ve bileşikler konusunda alternatif kavramlara sahip oldukları ortaya çıkmıştır.

Kimyasal madde kullanımı konusuna yönelik öğretmen adayların \%28.8'inin kimyasal madde tehlike sembollerinden $\mathbf{X}$ sembolünün tahriş edici kimyasallar için kullanılmayacağ 1 şeklinde bilimsel olarak yanlış bir anlayışa sahip oldukları belirlenmiştir (Tablo 5).

Tablo 5.

Kimyasal Madde Kullanımı Konusu ile ilgili Alternatif Kavramların Dağılımı

\begin{tabular}{|c|c|c|c|}
\hline Konu & Alternatif Kavramlar & $\mathrm{f}$ & $\%$ \\
\hline \multirow{2}{*}{ 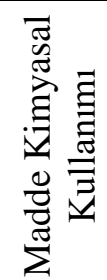 } & Sembolü tahriş edici kimyasallar için kullanılmaz. & 64 & 28.8 \\
\hline & Deterjan tahriş edici kimyasallardan değildir & 24 & 10.8 \\
\hline
\end{tabular}

Çözeltiler ve fiziksel özellikleri konusuna yönelik öğretmen adaylarının \%22.6's1 “tuz, saf suyun donma noktasını düşürmez", \%22.2'si " Otomobillerde antifriz olarak kullanılan etilen glikol (etandiol) suda çözünerek çözelti oluşturmaz.", \%21.2'si "Çözelti (su+ etilen glikol karışımı) kaynarken sıvının buhar basıncı açık hava basıncına eşit değildir." ve \%19.0'1 "Çözeltinin kaynama noktası saf suya göre yükselmez." gibi bilimsel olarak yanlış cevaplar verdikleri onların alternatif kavramlara sahip olduklarını göstermektedir (Tablo 6). 
Tablo 6.

Çözeltiler ve Fiziksel Özellikleri Konusu ile ilgili Alternatif Kavramların Dağılımı

\begin{tabular}{|c|c|c|c|}
\hline Konu & Alternatif Kavramlar & $\mathrm{f}$ & $\%$ \\
\hline \multirow{6}{*}{ 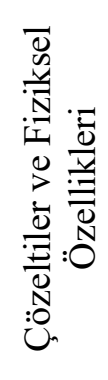 } & Tuz, saf suyun donma noktasını düsürmez. & 50 & 22.6 \\
\hline & $\begin{array}{l}\text { Otomobillerde antifriz olarak kullanılan etilen glikol } \\
\text { (etandiol) suda cözünerek cözelti olusturmaz. }\end{array}$ & 49 & 22.2 \\
\hline & $\begin{array}{l}\text { Çözelti (su + etilen glikol karışımı) Kaynarken sıvının buhar } \\
\text { basıncı açık hava basıncına eşit değildir. }\end{array}$ & 47 & 21.2 \\
\hline & Çözeltinin kaynama noktası saf suya göre yükselmez. & 42 & 19.0 \\
\hline & Donma noktası düșün çözelti daha geç donmaz. & 31 & 14.0 \\
\hline & Cëzelti karıștırılırsa çözünürlüğü artar. & 23 & 10.4 \\
\hline
\end{tabular}

Asit ve bazlar konusuna yönelik öğretmen adaylarına da var olan alternatif kavramlar Tablo 7'de gösterilmiştir.

Tablo7.

Asit ve Bazlar Konusu ile ilgili Alternatif Kavramların Dağılımı

\begin{tabular}{|c|c|c|c|}
\hline Konu & Alternatif Kavramlar & $\mathrm{f}$ & $\%$ \\
\hline $\begin{array}{l}\frac{\grave{\Xi}}{N} \\
\text { صี }\end{array}$ & Hidrojen içeren bütün maddeler asittir. & 40 & 18.0 \\
\hline$\frac{\overrightarrow{0}}{\stackrel{0}{\frac{0}{\alpha}}}$ & Bazın, asitle karıştırılması fiziksel bir olaydır. & 27 & 12.2 \\
\hline
\end{tabular}

Tablo 7 incelendiğinde öğretmenler adaylarının \%18.0'ında "Hidrojen içeren bütün maddeler asittir." \%12.2'sinde "Bazın, asitle karıştırılması fiziksel bir olaydır." şeklinde alternatif kavramlara sahip oldukları tespit edilmiştir.

Sıvıların özellikleri ve buharlaşma konusuna yönelik öğretmen adaylarının \%13.1'i kapalı kaplarda sıvının tamamının buharlaşacağı düşünmeleri onların alternatif kavramlara sahip olduklarını göstermektedir (Tablo 8).

Tablo 8.

Sıvıların Özellikleri ve Buharlaşma Konusu ile ilgili Alternatif Kavramların Dağılımı Alternatif Kavramlar $\mathrm{f}$ $\%$

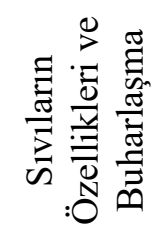

Kapalı kaplarda sıvının tamamı buharlaşır.

29

Gazlar ve Çözünürlük konusuna yönelik öğretmen adaylarının \%10.4'ü “Soda ve gazoz yapımındaki gazların çözünürlüğü basınca bağlı değildir." şeklinde bilimsel olarak yanlış kabul edilen cevaplarla alternatif kavramalara sahip oldukları tespit edilmiştir. 
Tablo 9.

Gazlar ve Çözünürlük Konusu ile ilgili Alternatif Kavramların Dağılımı

\begin{tabular}{|c|c|c|c|}
\hline Konu & Alternatif Kavramlar & $\mathrm{f}$ & $\%$ \\
\hline 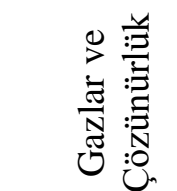 & $\begin{array}{l}\text { Soda ve gazoz yapımındaki gazların çözünürlüğü } \\
\text { basınca bağlı değildir. }\end{array}$ & 23 & 10.4 \\
\hline
\end{tabular}

Karışımlar ve ayırma yöntemleri konusuna yönelik öğretmen adaylarında var olan alternatif kavramlar Tablo 10'de verilmiştir.

Tablo 10.

Karışımlar ve Ayırma Yöntemleri Konusu ile ilgili Alternatif Kavramların Dağılımı

\begin{tabular}{|c|c|c|c|}
\hline Konu & Alternatif Kavramlar & $\mathrm{f}$ & $\%$ \\
\hline \multirow{7}{*}{ 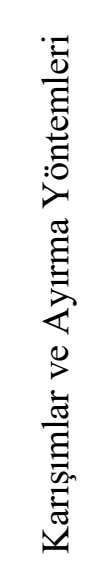 } & $\begin{array}{l}\text { Oluşan karışımda su buharlaştırılırsa tuz ve şeker birbirinden } \\
\text { ayrışır. }\end{array}$ & 83 & 37.4 \\
\hline & Asetik asit su ile karıştırıldığında kimyasal özelliği değişir. & 82 & 37.0 \\
\hline & Sıv1-sıvı homojen karışım buharlaşma yöntemiyle ayrılır. & 66 & 29.7 \\
\hline & Su ve asetik asitin yapıları benzer değildir. & 63 & 28.4 \\
\hline & $\begin{array}{l}\text { Bir kapta bulunan şeker -- tuz karışımına yeterince su ilave } \\
\text { edilirse homojen bir karışım oluşmaz. }\end{array}$ & 46 & 20.7 \\
\hline & Şekerli, tuzlu su karışımı heterojen bir yapıya sahiptir. & 44 & 19.8 \\
\hline & Sirke (asetik asit+su) homojen bir karışım değildir. & 38 & 17.3 \\
\hline
\end{tabular}

Tablo 10'a göre karışım ve ayırma yöntemleri konusunda öğretmen adaylarının \%37.4'ü “ Oluşan karışımda su buharlaştırılırsa tuz ve şeker birbirinden ayrışır.”, \%37.0'I "Asetik asit su ile karıștırıldığında kimyasal özelliği değișir.", \%29.7'si "Sıvı-sıvı homojen karışımı buharlaşma yöntemiyle ayrılır.", \%28.4'ü "Su ve asetik asitin yapıları benzer değildir." ve \%20.7'si "Bir kapta bulunan şeker-tuz karışımına yeterince su ilave edilirse homojen bir karışım oluşmaz" şeklinde bilimsel olarak yanlış kabul edilen cevaplarla alternatif kavramlara sahip oldukları tespit edilmiştir.

Isı ve sıcaklık konusuna yönelik olarak öğretmen adaylarının yaklaşık yarısının "Kalorifer peteğinden (radyatör) yayılan 1sı bir bileşik olduğunu ve \%11.3'ü de "Isı sadece yukarıya doğru hareket ettiğini ifadeleri onların alternatif kavramlara sahip olduklarını göstermektedir (Tablo11).

Tablo 11.

Isı ve Sıcaklık Konusu ile ilgili Alternatif Kavramların Dağılımı

\begin{tabular}{|c|c|c|c|}
\hline Konu & Alternatif Kavramlar & $\mathrm{f}$ & $\%$ \\
\hline$\frac{y}{\bar{y}}$ & Kalorifer peteğinden (radyatör) yayılan 1sı bir bileşiktir. & 106 & 47.8 \\
\hline 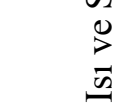 & Is1 sadece yukarıya doğru hareket eder. & 25 & 11.3 \\
\hline
\end{tabular}




\section{Tartışma, Sonuç ve Öneriler}

Bu çalışmada öğretmen adaylarının bazı kimya konularında (Kimyasal türler arası etkileşim: fiziksel ve kimyasal değişimler, kimyasal bağlar: molekül içi ve moleküller arası bağlar, kimya bilimi: elementler ve bileşikler, kimyasal madde kullanımı, çözeltiler ve fiziksel özellikleri, asitler ve bazlar, sıvıların özellikleri ve buharlaşma, gazlar ve çözünürlük, karışımlar ve ayırma yöntemleri, 1sı ve sıcaklık) alternatif kavramlara sahip olup olmadıkları incelenmiştir.

Maddenin fiziksel ve kimyasal değişim konusunu içeren cevaplar incelendiğinde öğretmen adaylarının alternatif kavramlara sahip oldukları belirlenmiştir. Alkış'ın (2006) yaptığı çalışmada 300 öğrenciden 98'sinin "kışın kar yağdığı için hava soğur." şeklinde alternatif kavrama sahip olduklarını ifade etmiştir. Başka bir çalışmada fiziksel olay sonunda yeni madde oluştuğu, yani hal değişiminin kimyasal olduğunu düşünen öğrencilerin olduğu rapor edilmiştir (Solsona, Izquierdo ve De Jong, 2003). Diğer bir çalışmada ise buzun suya dönüşümünü kimyasal değişim olarak düşünen öğrenciler ortaya çıkarılmıştır (Driver, Squires, Rushworth ve Wood-Robinson, 1994). Coştu, Ayas ve Ünal (2007) ise öğrencilerin kaynama sırasında sıcaklığın sabit olup olmamasını kavrayamadığını belirtmiş̧lerdir. Literatürdeki çalışmalar sunulan çalışmadaki bulguları destekler mahiyettedir.

Element ve bileşik konusunu içeren cevaplar incelendiğinde öğretmen adaylarının bilimsel olarak yanlış kabul edilen cevaplar verdikleri görülmektedir. Literatürde sunulan çalışmadaki sonuçları destekleyici çalışmalar mevcuttur. 2001 yılında yapılan çalışmada öğrencilerin atom, mol, molekül gibi kavramları anlamadıkları alternatif kavrama sahip oldukları ifade edilmiştir (Erdem, Yılmaz ve Morgil, 2001). Diğer bir çalışmada öğrencilerin atomun tek halde yani moleküler olmadığı düşüncesine sahip oldukları rapor edilmiştir (Arıkıl ve Kalın, 2010).

İyonik bileşikler konusunda öğretmen adaylarının bilimsel olarak kabul edilmeyen cevaplar sundukları ortaya çıkmıştır. Ünal, Ayas ve Çalık (2006) öğrencilerde NaCl'nin elektron paylaşımı ile oluşan bir bileşik olduğu şeklinde bir alternatif kavram tespit etmişlerdir. Ayrıca NaCl'nin kovalent bağa bulundurduğunu düşünen ve NaCl'nün kristal yapısını anlamayan öğrencilerin olduğu rapor edilmiştir (Baykan, 2008; Butts ve Smith, 1987; Kayalı ve Tarhan, 2004; Taber,1997).

Kimyasal madde kullanımı konusunda öğretmen adaylarının alternatif kavramlara sahip olduğu saptanmıştır. Meydan, Doğu ve Dinç (2009) deterjanların fazla kullanılmasının çevreye zarar verdiğini ve bunun insan eliyle olduğunu ifade eden öğrencileri beyan etmiştir. Fen bilgisi öğretmen adayları üzerinde yapılan bir çalışmada ise öğretmen adaylarının çok az bir kısmı kimyasal madde kullanımını özellikle deterjan kullanmayı azaltarak insanın ekolojiye yardımcı olacağını söylemişlerdir (Keleş ve Aydoğdu, 2010). Ayrıca etiket/ambalaj üstündeki kimyasal sembollerle yönelik bilgileri okumadan satın alan tüketicilerin olduğunu vurgulayan çalışmalar vardır (Çam, Kıray, Taştan ve Özkan, 2003; Soyucen, Aktan, Saral, Akgün ve Numanoğlu, 2006; Kiraz ve diğerleri, 2011).

Çözelti konusuna yönelik öğretmen adaylarında literatürdekine benzer alternatif kavramlar saptanmıştır. Yapılan bir araştırma günlük olaylardaki donma noktası düşmesini, öğrencilerin yanlış anladıklarını göstermiştir. Ayrıca öğrencilerin buzun erimesinin tuzdan aldığı 1sıdan olduğunu ve çözelti oluşumunun kimyasal olduğunu ifade eden öğrenciler tespit edilmiştir (Coştu, Ayas, Açıkkar ve Çalık, 2007). Karaer (2007) öğrencilerin, tuzlu suyun heterojen karışım olduğunu, süspansiyon karışımların homojen olduğunu düşündüklerini belirttiklerini rapor etmiştir. Ayrıca tuzun suda çözünmesinin kimyasal olarak niteleyen öğrenciler mevcuttur (Sökmen, Bayram ve Yılmaz, 2000; Uluçınar-Sağır, Tekin ve Karamustafaoğlu, 2012).

Bazlar konusuna yönelik öğretmen adaylarının literatürdeki çalışmaların sonuçlarını destekler nitelikte sonuçlara ulaşılmıştır. Literatürde öğrencilerin asit ve bazın fiziksel bir karışım meydana getireceğini ifade eden öğrencilerin olduğunu rapor edilmiştir (Demirci ve Özmen, 2012; Smith ve Metz, 1996; Zoller, 1990). Başka bir araştırmada baz olan maddelerin yapısında hidroksit iyonu $\left(\mathrm{OH}^{-}\right)$bulunması gerektiğini söyleyen öğrencilerin olduğu ortaya çıkmıştır (Yalçın-Ağgül, 2011). Yine yapılan diğer bir çalışmada ise bazların özelliği ile 
asitlerin özelliğinin tam olarak anlaşılmadığını; bazların özelliği olarak tatlarının ekşi olduğu, turnusol kâğıdını kırmızıya çevirdiği belirtilmiştir (Morgil, Yılmaz, Șen ve Yavuz, 2002).

Asitler konusunda öğretmen adaylarının literatürdeki çalışmaların sonuçlarını destekler mahiyette sonuçlara varılmıştır. Literatür incelendiğinde. Smith ve Metz (1996), Yalçın- Ağgül (2011) ve Zoller (1990) çalışmalarında öğrencilerde "Molekül yapısında hidrojen varsa asittir." şeklinde alternatif kavramın olduğunu saptanmıştır. Ayrıca başka bir çalışmada öğrenciler bazların tatlarını ekşi olacağını ve zayıf asit suda tamamen iyonlaşacağını ifade etmişlerdir (Morgil ve diğerleri, 2002). Farklı bir çalışmada ise öğrenciler zayif asitlerin suda iyonlaşamayacağını belirtmişlerdir (Çelikler ve Harman, 2015). Zoller (1990) ve Smith ve Metz (1996) öğrencilerin "pH sadece asitliğin bir ölçüsüdür, bazlığın ölçüsü değildir” şeklinde düşündüğünü rapor etmişlerdir. Bununla birlikte $\mathrm{pH}$ asitlik ve bazlıkta kullanılmaz şeklinde alternatif kavrama sahip öğrencilerinde var olduğu vurgulanmıştır (Demirci ve Özmen, 2012).

Sıvıların özellikleri ve buharlaşma konusunda öğretmen adaylarında literatürde sunulan çalışmadaki sonuçları destekleyen alternatif kavramlara ulaşı1mıştır. Kırıkkaya ve Güllü (2008) öğrencilerin "Suyun buharlaşması için kaynaması gerekir ve Su her sıcaklıkta buharlaşmaz" şeklinde alternatif kavrama ileri sürdüklerini belirtmiştir. Bununla birlikte "Buharlaşma sadece kaynama noktası ve daha yüksek sicaklıklarda olur" şeklinde alternatif kavram tespit edilmiştir (Aydoğan, Güneş ve Gülçiçek, 2003).

Çözeltilerin koligatif özellikleri konusunda öğretmen adaylarında saptanan alternatif kavramların literatürdeki alternatif kavramlarla örtüştüğü görülmektedir. Literatürde kaynama noktasının sadece atmosfer basıncına bağlı olduğun ve sıvıların belirli değişmeyen kaynama sicaklığının varlığından bahseden öğrenciler mevcuttur (Köseoğlu, Tümay ve Kavak, 2002). Coştu ve diğerleri (2007) ise "Kaynama noktası sıvının safsızlığına bağlı değildir" ve "Madde miktarının ve büyüklüğünün çözünürlüğe etki ettiği” belirten öğrencileri rapor etmiştir.

Gazlarda çözünürlük konusunda öğretmen adaylarında ortaya çıkan alternatif kavramların literatürde tespit edilenleri destekler nitelikte olduğu belirlenmiştir. Yapılan bir çalışmada öğrencilerin gazlı içeceklerin kapağı açıldığında sıcaklık değişiminden kabarcıklar oluştuğu, havadaki oksijenin çözündüğü ve gazların çözünürlüğünün basınçla ters orantılı olduğunu ifade eden öğrenciler mevcuttur (Erdem, Y1lmaz, Atav ve Gücüm, 2004). Benzer bir çalışmada öğrenciler gazozun soğuk içilme nedeni olarak, "Çözünürlük sıcaklık ilişkisi ile değil serinlik hissi vermesi için" cevabını vermişlerdir (Koray, Akyaz ve Köksal, 2007). Başka bir çalışmada gazoz bileşenlerine ayrılmaz şeklinde düşünen öğrenciler rapor edilmiştir (Karaer, 2007). Coştu ve diğerleri (2007) çözünürlüğe çözücü ve çözünen miktarının etki ettiğini belirten öğrencilerin bulunduğunu ifade etmişlerdir.

Ametaller ve özellikleri konusuna yönelik elde edilen sonuçlarla literatürdeki sonuçlar paralellik arz etmektedir. Şöyle ki Karamustafaoğlu ve Ayas (2002) farklı öğretim seviyesindeki öğrencilerin ametal ve metal kavramlarını karıştırdıkları ve özellikleriyle ilgili yanlış anlamaya sahip olduklarını vurgulamıştır. Sunulan çalışmayı destekleyen başka bir çalışmada " $\mathrm{HCl}$ iyonik yapılı bir bileşiktir" şeklinde bir alternatif kavramın varlığına dikkat çekilmiştir (Coll ve Taylor, 2001; Öztürk-Ürek ve Tarhan, 2005).

Bileşikler ve adlandırılması konusundan ortaya çıkan sonuçlar literatürdeki sonuçlarla örtüşmektedir. Yapılan bir araştırmada öğrencilerin $\mathrm{CO}_{2}$ 'nin iyonik bileşik olduğunu ve iyonik ve kovalent bileşikleri birbirine karıştırdıkları görülmüştür (Taber, 1994; Ünal ve diğerleri, 2006). Diğer bir çalışmada ise kovalent bağların elektron alışverişi sonucu oluştuğu şeklinde alternatif kavram tespit edilmiştir (Şen ve Yılmaz, 2013). Butts ve Smith (1987) ise öğrencilerin sodyum ve klor atomlarının kovalent bağ yaptığını ileri sürdüklerini rapor etmiştir.

Kimyasal bağlar konusunda öğretmen adaylarının literatürde de yer alan alternatif kavramlara benzer sonuçlar tespit edilmiştir. Öğrenciler atomların soygaza benzemek için kovalent bağ yaptıklarını ifade etmişlerdir (Akkuş, Tüzün ve Eyceyurt, 2013; Baykan, 2008; Ünal, Coştu ve Ayas, 2010). Kadayıfçı (2001) soygazların gerektiğinde molekül içi bağ yaptığı ifade eden öğrencilerin olduğunu rapor etmiştir. Ayrıca öğrencilerin molekül içi ve moleküller arası bağları ayırt etmekte sıkıntı yaşadıkları, molekül polarlığı ve bağ polarlığını karıştırdıkları tespit edilmiştir (Nicoll, 2001; Özmen, 2003; Peterson, Treagust ve Garnet, 1989; Tan ve 
Treagust, 1999). Başka bir çalışmada ise öğrenciler bağ ve molekül polarlığını seçememişlerdir (Yılmaz ve Morgil, 2001). Diğer çalışmada iyonik bağın ametal atomları arasında oluştuğunu ifade eden öğrencilerin olduğu belirlenmiştir (Ünal ve diğerleri, 2006). Özbayrak ve Kartal (2012) öğrencilerde ametallerin iyonik bağ yaptı̆̆ı, kovalent bağın metal ile ametal arasında oluştuğu ve özdeş atomlar arasında polar bağ meydana geldiğine dair alternatif kavramın mevcut olduğunu bulmuştur. Bunun yanı sıra öğrencilerin molekül içi ve moleküller arası bağları karıştırdıkları, fiziksel değişim sırasında molekül içi bağların kırıldığı alternatif kavrama sahip olduklarını rapor edilmiştir (Kabapınar ve Adik, 2006). Ayrıca öğrenciler sıvılar 1sı alıp buharlaşırken molekül içi bağların koptuğunu (Karslı ve Ayas, 2013), su molekülleri arasındaki bağları çizemediğini, zayıf etkileşimler ile güçlü etkileşimleri karıştırdıklarını (Ültay, 2014) ve suya 1S1 verince kimyasal bağ olan molekül içi bağın kırılıp koptuğunu belirtmişlerdir (Şen ve Yılmaz, 2013). Dahası Kadayıfçı (2001) çalışmasında öğrencilerin metalik bağı anlamadıklarını belirlemiştir. Farklı bir çalışmada öğrencilerin metallerin yapısını ve metalik bağ kavrayamadıkları ifade edilmiştir (Atasoy, Kadayıfçı ve Akkuş, 2003). Bununla birlikte alaşımlardaki metalik bağın kimyasal olay olduğu vurgulayan öğrencilere rastlanmıştır (Şen ve Y1lmaz, 2013).

Maddenin fiziksel ve kimyasal değişimi konusunda literatürde tespit dilen benzer alternatif kavramlara bu çalışmada da ulaşılmıştır. Yapılan araştırmalar incelendiğinde öğrencilerin kimyasal değişim ile fiziksel değişimi karıştırdıkları (Sökmen ve diğerleri, 2000) ve şekerin suda erimesini, alkolün suda çözünmesini, yoğurtan ayran eldesini kimyasal olaylara örnek olarak vermişlerdir (Kolomuç ve Açışl1, 2012). Bu sonuçlar sunulan çalışmadaki sonuçları destekler mahiyettedir.

Karışımları ayrıştırma yöntemleri konusu ile ilgili olarak literatürde ortaya çıkan alternatif kavramlarla örtüşen sonuçlara ulaşılmıştır. Literatürde çözeltideki maddelerin yeni bir madde oluşturduğu, diğer bir deyişle kimyasal değişime uğradıkları (Coştu ve diğerleri, 2007), şekerin suda çözünmesini kimyasal olduğunu, tuzun eriyerek kaybolduğu ve buharlaşma sırasında su buharlaşınca tuzun da buharlaştığını söyleyen öğrencilere rastlanmıştır (Yıldırım, Er Nas, Şenel ve Ayas, 2007).

Is1 ve S1caklık konusunda ise literatürde belirtilen alternatif kavramlarla paralellik gösteren sonuçlara ulaşılmışıır. Literatürde 1sı maddedir ve enerji çeşidi değildir (Kırıkkaya ve Güllü, 2008), 1sı ve sıcaklığın aynı olduğunu, sıcaklığın bir maddeye transfer edilebileceğini (Turgut ve Gürbüz, 2011) ve 1sıy1 enerji çeşidi olarak değerlendiren öğrencilerin olduğu rapor edilmiştir (Aydoğan ve diğerleri, 2003).

Tüm bu sonuçlarla öğretmen adaylarının kimyasal türler arası etkileşim: fiziksel ve kimyasal değişimler, kimyasal bağlar: molekül içi ve moleküller arası bağlar, elementler ve bileşikler, kimyasal madde kullanımı, çözeltiler ve fiziksel özellikler, asit ve bazlar, sıvıların özellikleri ve buharlaşma, gazlar ve çözünürlük, karışımlar ve ayırma yöntemleri, 1s1 ve sıcaklık konularına yönelik literatürde bahsedilen alternatif kavramların halen daha devam etmekte olduğu ve giderilemediği TDA tekniği kullanılarak hazırlanan kavram testi ile ortaya konulmuştur. Sonuç olarak; TDA tekniği kullanılarak fen eğitimi ve diğer alanlarda özellikle kimyanın farklı konularda teşhis edici kavram testleri hazırlanarak öğrencilerin, öğretmen adaylarının ve öğretmenlerin alternatif kavramlara sahip olup olmadıkları belirlenebilir. TDA tekniği gerek üniversite gerekse ilköğretim ve ortaöğretim öğrencilerindeki alternatif kavramların tespiti ve giderilmesine yönelik olarak kullanılabilir. İlgili kurumlar merkezi sınavlarda TDA tekniği kullanarak sorular hazırlayabilir ve bu sayede öğrencilerin anlayışlarını ortaya çıkarılabilir. Bununla birlikte TDA tekniği ile hazırlanan kavram testi hem araştırmacılara hem de öğretmenlere sınıf ya da laboratuvar ortamında yardımcı olmada önemli katkılar sunabilir.

\section{Kaynaklar}

Akkuş, H., Tüzün, Ü. N. ve Eyceyurt, G. (2013). Kovalent bağlar konusunda öğrenci imaj ve yanlış kavramalarının belirlenmesi. Ahi Evran Üniversitesi Kırşehir Eğitim Fakültesi Dergisi, 14(1), 287-303. 
Alkış, S. (2006). İlköğretim öğrencilerinin yă̆ış kavramını algılama biçimleri. İlköğretim Online, 5(2), 126-140.

Arıkıl, G. ve Kalın, B. (2010). Çözeltiler konusunda üniversite öğrencilerinin sahip olduğu kavram yanılgıları. Necatibey Eğitim Fakültesi Elektronik Fen ve Matematik Eğitimi Dergisi, 4(2), 177-206.

Atasoy, B., Kadayıf̧ı, H. ve Akkuş, H. (2003). Lise 3.sınıftaki öğrencilerin kimyasal bağlar konusundaki yanlış kavramaları ve bunların giderilmesi üzerine yapılandırmacı yaklaşımın etkisi. Türk Eğitim Bilimleri Dergisi, 1(1), 61-79.

Aydoğan, S., Güneş, B. ve Gülçiçek, Ç. (2003). Isı ve sıcaklık konusunda kavram yanılgıları. Gazi Eğitim Fakültesi Dergisi, 23(2), 111-124.

Bahar, M. (2001). Çoktan seçmeli testlere eleştirel bir yaklaşım ve alternatif metotlar. Kuram ve Uygulamada Ë̆itim Bilimleri Dergisi, 9, 4-6.

Baykan, F. (2008). Kimya ve fen bilgisi ögrretmen adaylarl ile on birinci sınıf ögrencilerinin kimyasal bağlanma hakkındaki anlamalarının ve yanılgılarının karşılaş̧ırılması (Yayımlanmamış yüksek lisans tezi). Trabzon: Karadeniz Teknik Üniversitesi Fen Bilimleri Enstitüsü.

Butts, B. ve Smith, R. (1987). HSC chemistry students' understanding of the structure and properties of molecular and ionic compounds. Research in Science Education, 17, 192201. doi.org/10.1007/BF02357187

Büyüköztürk, Ş., Çakmak, E. K., Akgün, Ö. E, Karadeniz, Ş. ve Demirel, F. (2012). Bilimsel araştırma yöntemleri (11.baskı). Ankara: Pegem Akademi.

Canpolat, N. ve Pınarbaşı, T. (2011). Bazı kimya kavramlarına yönelik iki kademeli çoktan seçmeli bir testin geliştirilmesi ve uygulanması. Erzincan Üniversitesi Ĕ̈itim Fakültesi Dergisi, 13(1), 55-80.

Canpolat, N. ve Pınarbaşı, T. (2012). Kimya öğretmen adaylarının kaynama olayı ile ilgili anlayışları: Bir olgubilim çalışması. Erzincan Üniversitesi Eğitim Fakültesi Dergisi, 14(1), 81-96.

Cartrette, D. P. ve Mayo, P. M. (2011). Students' understanding of acids/bases in organic chemistry contexts. Chemistry Education Research and Practice, 12(1), 29-39. doi.org/10.1039/C1RP90005F

Coll, R. K. ve Taylor, N. (2001). Alternative conceptions of chemical bonding held by upper secondary and tertiary students. Research in Science \& Technological Education, 19(2), 171-191. doi.org/ 10.1080/02635140120057713

Coştu, B., Ayas, A., Açıkkar, E. ve Çalık, M. (2007). Çözünürlük konusu ile ilgili kavramlar ne düzeyde anlaş1lyyor?. Boğaziçi Üniversitesi Eğitim Dergisi, 24(2), 13-28.

Coştu, B., Ayas, A. ve Ünal, S. (2007). Kavram yanılgıları ve olası nedenleri: Kaynama kavramı. Kastamonu Eğitim Dergisi, 15(1), 123-136.

Çam, H., Kıray, E., Taştan, Y. ve Özkan, H. Ç. (2003). İstanbul üniversitesi cerrahpaşa tıp fakültesi çocuk sağlığı ve hastalıkları anabilim dalı acil servisinde izlenen zehirlenme olguları orijinal araştırma. Türk Pediatri Arşivi, 38(4), 233-239.

Çelen, Ü. (2014). Tanılayıcı dallanmış ağacın psikometrik özellikleri. Eğitim ve Bilim, 39(174), 201-213. doi.org/10.15390/EB.2014.2690

Çelikler, D. ve Harman, G. (2015). Fen bilgisi öğrencilerinin asit ve bazlarla ilgili zihinsel modellerinin analizi. Mustafa Kemal Üniversitesi Sosyal Bilimler Enstitüsü Dergisi, 12(32), 244-264.

Çetin-Dindar, A. ve Geban, O. (2011). Development of a three-tier test to assess high school students' understanding of acids and bases. Procedia-Social and Behavioral Sciences, 15, 600-604. doi.org/10.1016/j.sbspro.2011.03.147

Demirci, Ö. ve Özmen, H. (2012). Zenginleştirilmiş bir öğretim materyalinin öğrencilerin asit ve bazlarla ilgili anlamalarına etkisi. Amasya Üniversitesi Ĕgitim Fakültesi Dergisi, $1(1), 1-17$. 
Dönmez-Usta, N. ve Ayas, A. (2010). Common misconceptions in nuclear chemistry unit. Procedia-Social and Behavioral Sciences, 2(2), 1432-1436. doi.org/10.1016/j.sbspro. 2010.03.214

Driver, R., Squires, A., Rushworth, P. ve Wood-Robinson, V. (1994). Making sense of secondary science: Research into children's ideas (2nd Ed.). London: Routledge.

Erdem, E., Yılmaz, A., Atav, E. ve Gücüm, B. (2004). Öğrencilerin' madde' konusunu anlama düzeyleri, kavram yanılgıları, fen bilgisine karşı tutumları ve mantıksal düşünme düzeylerinin araştırılması. Hacettepe Üniversitesi Eğitim Fakültesi Dergisi, 27(27), 7482.

Erdem, E., Y1lmaz, A. ve Morgil, F. İ. (2001). Kimya dersinde bazı kavramlar öğrenciler tarafindan ne kadar anlaş1liyor? Hacettepe Üniversitesi Eğitim Fakültesi Dergisi, 20(20), 65-72.

Erdemir, A. Ö., Geban, Ö. ve Uzuntiryaki, E. (2000). Freshman students misconceptions in chemical equilibrium. Hacettepe Üniversitesi Ë̆itim Fakültesi Dergisi, 18(18), 79-84.

Ergin, D. Y. (1995). Ölçeklerde geçerlik ve güvenirlik. Marmara Üniversitesi Atatürk Ë̆itim Fakültesi Eğitim Bilimleri Dergisi, 7(1), 125-148.

Field, A. (2013). Discovering statistics using IBM SPSS statistics (4th Ed.). London: SAGE Publications.

Fraeklen, J. R., Wallen, N. E. ve Hyun, H. H. (2011). How to design and evaluate research in education (8th Ed.). New York: McGraw-Hill.

Gecgel, G. ve Sekerci, A. R. (2015). Developing a concept test for chemistry topics by using the diagnostic branched tree (DBT) technique. Oxidation Communications, 38(1A), 530539.

Herrmann-Abell, C. F. ve DeBoer, G. E. (2011). Using distractor-driven standards-based multiple-choice assessments and Rasch modeling to investigate hierarchies of chemistry misconceptions and detect structural problems with individual items. Chemistry Education Research and Practice, 12(2), 184-192. doi.org/10.1039/C1RP90023D

Johnstone, A. H., McAlpine, E. ve MacGuire, P. R. P. (1986). Branching trees and diagnostic testing. A Journal for Further and Higher Education in Scotland, 2, 4-7.

Kabapınar, F. M. ve Adik, B. (2006). Ortaöğretim öğrencilerinin kovalent bağda elektronların konum ve hareketlerini anlama biçimleri. M. U. Atatürk Eğitim Fakültesi Eğitim Bilimleri Dergisi, 23, 205-228.

Kadayıf̧̧ı, H. (2001). Lise 3. sınıftaki öğrencilerin kimyasal bağlar konusundaki yanlış kavramalarının belirlenmesi ve yapılandırıcı yaklaşımın yanlış kavramaların giderilmesi üzerine etkisi (Yayımlanmamış yüksek lisans tezi). Ankara: Gazi Üniversitesi Eğitim Bilimleri Enstitüsü.

Karaer, H. (2007). Sınıf öğretmeni adaylarının madde konusundaki bazı kavramların anlaşılma düzeyleri ile kavram yanılgılarının belirlenmesi ve bazı değişkenler açısından incelenmesi. Kastamonu Eğitim Dergisi, 15(1), 199-210.

Karamustafaoğlu, S. ve Ayas, A. (2002). Farkl1 öğrenim seviyelerindeki öğrencilerin 'metal, ametal, yarı metal ve alaşım' kavramlarını anlama düzeyleri ve kavram yanılgıları. M.Ü. Atatürk Ĕgitim Fakültesi Eğitim Bilimleri Dergisi 15, 151-162.

Karaoğlan, C. ve Çatak, M. (2005). Tanılayıcı dallanmiş ağaç yöntemiyle ölçme değerlendirme: 7. sinıf matematik dersi için bir uygulama, 14. Ulusal Eğitim Bilimleri Kongresi. 28-30 Eylül 2005, Denizli: Pamukkale Üniversitesi Eğitim Fakültesi.

Karslı, F. ve Ayas, A. (2013). Fen bilgisi öğretmen adaylarının kimya konularında sahip oldukları alternatif kavramlar. Necatibey Eğitim Fakültesi Elektronik Fen ve Matematik Ĕ̈itimi Dergisi, 7(2), 284-312.

Kayalı, H. A. ve Tarhan, L. (2004). İyonik bağlar konusunda kavram yanılgılarının giderilmesi amacıyla yapılandırmacı-aktif öğrenmeye dayalı bir rehber materyal uygulaması. Hacettepe Üniversitesi Ĕ̈itim Fakültesi Dergisi, 27(27), 145-154.

Keleş, Ö. ve Aydoğdu, M. (2010). Fen bilgisi öğretmen adaylarının ekolojik ayak izlerini azaltma yolları konusundaki görüşleri. Türk Fen Eğitimi Dergisi, 7(3), 171-187. 
Kırıkkaya, E. B. ve Güllü, D. (2008). İlköğretim beşinci sınıf öğrencilerinin 1s1-sıcaklık ve buharlaşma-kaynama konularındaki kavram yanılgıları. İlköğretim Online, 7(1), 15-27.

Kiraz, E., Demirkıran, F., Memiş, S., Ergin, F., Önde, M., Bilgen, M. A. ve Beşer, E. (2011). Ev temizlik malzemeleri farkındalık araştırması-aydın. TAF Preventive Medicine Bulletin, 10(4), 198-211.

Kirbulut, Z. D. ve Geban, O. (2014). Using three-tier diagnostic test to assess students' misconceptions of states of matter. Eurasia Journal of Mathematics, Science \& Technology Education, 10(5), 509-521. doi.org/10.12973/eurasia.2014.1128a

Kocaarslan, M. (2012). Tanılayıcı dallanmış ağaç tekniği ve ilköğretim 5. sınıf fen ve teknoloji dersi maddenin değişimi ve tanınması adlı ünitede kullanımı. Mustafa Kemal Üniversitesi Sosyal Bilimler Enstitüsü Dergisi, 9(18), 269-279.

Kolomuç, A. ve Açışl1, S. (2012). 9. sınıf öğrencileri ile fen bilgisi öğretmen adaylarının fiziksel ve kimyasal olaylar konusunda ki alternatif kavramlarının karşılaştırılması. Eğitim ve Öğretim Araştırmaları Dergisi, 4(14), 121-125.

Kolomuç, A. ve Tekin, S. (2011). Chemistry teachers' misconceptions concerning concept of chemical reaction rate. Eurasian Journal of Physics and Chemistry Education, 3(2), 84101.

Koray, Ö., Akyaz, N. ve Köksal, M. S. (2007). Lise öğrencilerinin “çözünürlük” konusunda günlük yaşamla ilgili olaylarda gözlenen kavram yanılgıları. Kastamonu Eğitim Dergisi, 15(1), 241-250.

Köseoğlu, F., Tümay, H. ve Kavak, N. (2002, Eylül). Yapılandırıcı öğrenme teorisine dayanan etkili bir öğretim yöntemi -tahmin et, gözle, açıkla- buz ile su kaynatılabilir mi? V. Fen Bilimleri ve Matematik Eğitimi Kongresi Bildiriler Ankara (16-18 Eylül 2002), içinde (1-15). Ankara: Orta Doğu Teknik Üniversitesi,.

Mavi, M. (2008). Lise ögrencilerinin radyasyon konusundaki kavram yanılgılarının tespiti (Yayımlanmamış yüksek lisans tezi). Isparta: Süleyman Demirel Üniversitesi Fen Bilimleri Enstitüsü.

McMillan, J. H. ve Schumacher, S. (2014). Research in education: Evidence-based inquiry (7th ed.). Harlow: Pearson Higher Ed.

Meydan, A., Doğu, S. ve Dinç, M. (2009). Öğretmen adaylarının çevre sorunları konusundaki farkındalık ve duyarlılıkları. Selçuk Üniversitesi Ahmet Keleşoğlu Eğitim Fakültesi Dergisi, 28, 153-168.

Morgil, İ., Yılmaz, A., Şen, O. ve Yavuz, S. (2002). Öğrencilerin asit-baz konusunda kavram yanılgıları ve farklı madde türlerinin kavram yanılgılarını saptama amacıyla kullanımı. V. Ulusal Fen Bilimleri ve Matematik Eğitimi Kongresi. Ankara: Orta Doğu Teknik Üniversitesi, 16-18 Eylül 2002, 1-5.

Nicoll, G. (2001). A report of undergraduates' bonding misconceptions. International Journal of Science Education, 23, 707-730.

Özbayrak, Ö. ve Kartal, M. (2012). Ortaöğretim 9. sınıf kimya dersi" bileşikler" ünitesi ile ilgili kavram yanılgılarının iki aşamalı kavramsal anlama testi. Buca Eğitim Fakültesi Dergisi, 32, 144-156.

Özmen, H. (2003). Kimya öğretmen adaylarının asit ve baz kavramlarıyla ilgili bilgilerini günlük olaylarla ilişkilendirebilme düzeyleri. Kastamonu Eğitim Dergisi, 11(2), 317324.

Öztürk-Ürek, R. ve Tarhan, L. (2005). Kovalent bağlar konusundaki kavram yanılgılarının giderilmesinde yapılandırmacılığa dayalı bir aktif öğrenme uygulaması. Hacettepe Üniversitesi Eğitim Fakültesi Dergisi, 28(28), 168-177.

Peterson, R. F., Treagust, D. F. ve Garnett, P. (1989). Development and application of a diagnostic instrument to evaluate grade-11 and-12 students' concepts of covalent bonding and structure following a course of instruction. Journal of Research in Science Teaching, 26(4), 301-314. doi.org/10.1002/tea.3660260404 
Pınarbaşı, T., Canpolat, N. ve Sözbilir, M. (2009). Sınıf öğretmenliği öğrencilerinin mumun yanmasıyla ilgili anlayışları. Erzincan Üniversitesi Fen Bilimleri Enstitüsü Dergisi, 2(1), 73-88.

Pınarbaşı, T., Doymuş, K., Canpolat, N. ve Bayrakçeken, S. (1998). Üniversite kimya bölümü öğrencilerinin bilgilerini günlük yaşamla ilişkilendirebilme düzeyleri. III. Fen Bilimleri Eğitimi Sempozyumu (23-25 Ekim 1998), Trabzon: Karadeniz Teknik Üniversitesi Fatih Eğitim Fakültesi.

Sekerci, A. R. (2015). Development of diagnostic branched tree test for high school chemistry concepts. Oxidation Communications, 38(2A), 1060-1067.

Sekerci, A. R. ve Canpolat, N. (2014). Impact of argumentation in the chemistry laboratory on conceptual comprehension of Turkish students. Educational Process: International Journal, 3(1-2), 19-34. doi.org/ 10.12973/edupij.2014.312.2

Smith, K. J. ve Metz, P. A. (1996). Evaluating student understanding of solution chemistry through microscopic representations. Journal of Chemical Education, 73, 233-235. doi.org/10.1021/ed073p233

Solsona, N. R., Izquierdo, M., ve De Jong, O. (2003). Exploring the development of students' conceptual profiles of chemical change. International Journal of Science Education, 25(1), 3-12. doi.org/10.1080/09500690010006536

Soyucen, E., Aktan, Y., Saral, A., Akgün, N. ve Numanoğlu, A. Ü. (2006). Sakarya bölgesinde çocukluk çağı zehirlenmelerinin geriye dönük değerlendirilmesi. Çocuk Să̆llğ ve Hastalıkları Dergisi, 49(4), 301-306.

Sökmen, N., Bayram, H. ve Yılmaz, A. (2000). 5., 8. ve 9. sınıf öğrencilerinin fiziksel değişim ve kimyasal değişim kavramlarını anlama seviyeleri. Atatürk Eğitim Fakültesi Eğitim Bilimleri Dergisi, 12, 261-266.

Şahin, Ç. ve Çepni, S. (2011). Developing of the concept cartoon, animation and diagnostic branched tree supported conceptual change text: "gas pressure". Eurasian Journal of Physics and Chemistry Education, 1(1), 25-33.

Şen, Ş. ve Yılmaz, A. (2013). Kimyasal bağlarla ilgili fenomenografik bir çalışma. Necatibey Eğitim Fakültesi Elektronik Fen ve Matematik Eğitimi Dergisi, 7(2), 144-177.

Taber, K. S. (1994). Misunderstanding the ionic bond. Education in Chemistry, 31(4), 100-103.

Taber, K. S. (1997). Student understanding of ionic bonding: molecular versus electrostatic framework? School Science Review, 78(285), 85-95.

Taber, K. S. ve Tan, K. C. D. (2011). The insidious nature of 'hard-core'alternative conceptions: Implications for the constructivist research programme of patterns in high school students' and pre-service teachers' thinking about ionisation energy. International Journal of Science Education, 33(2), 259-297. doi.org/10.1080 /09500691003709880

Tan, K. C. D. ve Treagust, D. F. (1999). Evaluating students' understanding of chemical bonding. School Science Review, 81(294), 75-84.

Turgut, Ü. ve Gürbüz, F. (2011). Effects of teaching with 5E model on students' behaviors and their conceptual changes about the subject of heat and temperature. International Online Journal of Educational Sciences, 3(2), 679-706.

Tüysüz, C. (2009). Development of two-tier diagnostic instrument and assess students' understanding in chemistry. Scientific Research and Essay, 4(6), 626-631.

Uluçınar-Sağır, Ş., Tekin, S. ve Karamustafaoğlu, S. (2012). Sınıf öğretmeni adaylarının bazı kimya kavramlarını anlama düzeyleri. Dicle Ziya Gökalp Eğitim Fakültesi Dergisi, 19, $112-135$.

Ültay, N. (2014). 12. sınıf öğrencilerinin güçlü ve zayıf etkileşimler hakkındaki kavramsal bilgilerinin belirlenmesi. Mehmet Akif Ersoy Üniversitesi Eğitim Fakültesi Dergisi, 32, $1-21$.

Ünal, S., Ayas, A. ve Çalık, M. (2006). Lise öğrencilerinin iyonik bağla ilgili yanlış kavramları: bir örnek olay çalışması. Eğitim ve Bilim, 31(141), 3-12.

Ünal, S., Coştu, B. ve Ayas, A. (2010). Secondary School students' misconceptions of covalent bonding. Journal of Turkish Science Education, 7(2), 3-29. 
Van Blerkom, M. (2009). Measurement and statistics for teachers. New York, Routledge.

Voska, K. ve Heikkinen, H. (2000). Identification and analysis of students' conceptions used to solve chemical equilibrium problems. Journal of Research in Science Teaching, 37(2), 160-176. doi.org/10.1002/(SICI)1098-2736(200002)37:2<160:AID-TEA5>3.0.CO;2-M

Yadigaroğlu, M. ve Demircioğlu, G. (2012). Kimya öğretmen adaylarının kimya bilgilerini günlük hayattaki olaylarla ilişkilendirebilme düzeyleri. Ĕğitim ve Öğretim Araştırmaları Dergisi, l(2), 165-171.

Yağbasan, R. ve Gülçiçek, Ç. (2003). Fen öğretiminde kavram yanılgılarının karakteristiklerinin tanımlanması. Pamukkale Üniversitesi Eğitim Fakültesi Dergisi, 13(13), 102-120.

Yalçın-Ağgül, F. (2011). Fen bilgisi öğretmen adayların asit-baz konusunda sahip oldukları kavram yanılgılarının sınıf düzeylerine göre değişiminin incelenmesi. Türk Fen Eğitimi Dergisi, 8(3), 161-173.

Yıldırım, N., Er-Nas, S., Şenel, T. ve Ayas, A. (2007). Öğrencilerin kavram yanılgılarını gidermeye yönelik örnek bir etkinlik geliştirilmesi, uygulanması ve değerlendirilmesi, Edu7, 2(4), 1-22.

Yılmaz, A. ve Morgil, İ. (2001). Üniversite öğrencilerinin kimyasal bağlar konusundaki kavram yanılgılarının belirlenmesi. Hacettepe Üniversitesi Ĕ̈itim Fakültesi Dergisi 20, 172-178.

Zoller, U. (1990). Students' misunderstandings and misconceptions in college freshman chemistry (general and organic). Journal of Research in Science Teaching, 27(10), 1053-1065. doi.org/10.1002/tea.3660271011

\section{Extended Abstract}

\section{Introduction}

The diagnostic branched tree (DBT) is an identification tool used to identify whether meaningful learning takes place, to identify misunderstood alternative concepts in students' minds, and to reveal the reasons for missing learning. This technique reveals the existing incorrect associations, strategies, and information in students' minds and it emphasizes that these play an important role in effective learning and teaching (Bahar, 2001; Johnstone, McAlpine \& MacGuire, 1986). DBT also plays a great role in students' self-assessments and facilitates teachers to realize and correct students' faults (Kocaarslan, 2012; Şahin \& Çepni, 2011). Through making use of the DBT technique, which is an alternative assessment and evaluation instrument, whether students' own alternative concepts in chemistry topics can be revealed. The purpose of the current study is to reveal whether teacher candidates possess alternative concepts in some chemistry topics physical and chemical changes, chemical bonds: inter and intra molecular bonds, chemistry science: elements and compounds, chemical substance use, solutions and properties of solutions, acids and bases, properties of liquids and evaporation, gases and solubility, mixtures and methods for separating the components of a mixture, heat and temperature) via the use of concept test prepared with the DBT technique. The study sought to answer the question: What are the alternative concepts science education and primary school education teacher candidates possess in some chemistry topics?

\section{Method}

The study made use of a survey method. This kind of descriptive research defines a problem or a case as completely as possible and it is the most commonly preferred research method in educational surveys (Büyüköztürk, Çakmak, Akgün, Karadeniz \& Demirel, 2012; McMillan \& Schumacher, 2014). The sample of the study consisted of 222 teacher candidates (161 females, 61 males) studying at the primary education and science teaching departments at the education faculty of Dumlupinar University in the academic year of 2013-2014. Participation in the study was voluntary. A 22 item concept test designed by the researchers using the diagnostic branched tree technique was applied in the study (Gecgel \& Sekerci, 2015). The mean difficulty index value was measured as 0.55 , and the mean item discrimination index value was calculated as 
0.35. Following the statistical analysis, the internal consistency coefficient of the concept test was measured as 0.75. tables (Gecgel \& Sekerci, 2015). The data obtained from concept test which was developed through the Diagnostic branched tree technique was analyzed with statistical programs. Each response given by the participant teacher candidates to each item in the concept test was examined and the alternative concepts were presented with frequency and percent values in.

\section{Result and Discussion}

In terms of the chemical bonds topic and the statements of 50.9\% of the participant teacher candidates, specific alternative concepts were revealed, such as that the inter-molecules bonds were the bonds within the molecules, there were not apolar covalent bonds among the same kind of non-metals $(20.3 \%$ of teacher candidates) and there were not covalent bonds among nonmetal atoms. $35.7 \%$ of the teacher candidates stated that "...the ionic bond exists among only non-metals and through the sharing of electrons," $24.8 \%$ of them stated that "...solid composites with ionic bonds conduct electricity." $24.0 \%$ stated that "...the gases $\mathrm{O}_{2}$ and $\mathrm{CO}_{2}$ do not comprise only through electron cooperation among non-metals." $20.3 \%$ of the teacher candidates stated that "...an element is not of molecular or atomic features." $18.1 \%$ of them stated that "...non-metals (except Hydrogen) are not located in right side of the periodic table." Considering these statements, the participant teacher candidates were seen to give incorrect responses in scientific terms. In other words, teacher candidates were observed to possess alternative concepts. $18.0 \%$ of the participant teacher candidates possessed alternative concepts such as "All substances including hydrogen are acids." And $12.2 \%$ of them stated that "...the inclusion of bases with acids is a physical event." Regarding liquids' characteristics and evaporation topics, the fact that $13.1 \%$ of the teacher candidates thought that all of the liquid would evaporate in closed vessels indicates that they possess alternative concepts. The study examines whether teacher candidates possess alternative concepts in some chemistry topics (physical and chemical changes, chemical bonds: inter and intra molecular bonds, chemistry science: elements and compounds, chemical substance use, solutions and properties of solutions, acids and bases, properties of liquids and evaporation, gases and solubility, mixtures and methods for separating the components of a mixture, heat and temperature). In the literature, similar alternative concepts among teacher candidates were found in the solutions topic. A study revealed that the freezing point depression in daily events was misunderstood by $27 \%$ of the students. Also, some other students were observed to express that ice melts due to the heat it takes from salt, and that solutions' compositions are chemical. Karaer (2007) reported that the students indicated that salty water was a heterogeneous mixture, that suspension mixtures were homogenous. Additionally, students stated that the solution of salt in water was a chemical event. The findings in the literature are in accordance with the current study's findings.

On the topic of bases, the literature findings related to teacher candidates' alternative concepts present similar results with the current study. In the literature, it is reported that there were students expressing that acid and bases compose a physical mixture. In a different work, there were reported students stating that there should be a hydroxide ion $\left(\mathrm{OH}^{-}\right)$in the substances which were bases. In another study, it was revealed that the characteristics of acids and bases were not understood thoroughly, and the students indicated bases tasted sour and that they transformed litmus paper into the red.

In terms of the acids topic, the literature also reveals supporting results with the current study's findings. In a review of the literature, in their studies, Smith and Metz (1996), Yalçın Agggül (2011) and Zoller (1990) reported that the students had alternative concepts like "If there is hydrogen in a molecule, it's an acid." Also in another study, the students claimed that the bases tasted sour, and mild acid would ionize in water completely. Zoller (1990) and Smith and Metz (1996) reported students saying that "...pH is only a criteria of acidity, not alkalinity." However, some students also stated that $\mathrm{pH}$ cannot be used in acidity and alkalinity. The statements and findings above indicate that teacher candidates still possess alternative concepts mentioned in the literature in some topics in chemistry such physical and chemical changes, 
Geçgel ve Şekerci

chemical bonds: inter and intra molecular bonds, chemistry science: elements and compounds, chemical substance use, solutions and properties of solutions, acids and bases, properties of liquids and evaporation, gases and solubility, mixtures and methods for separating the components of a mixture, heat and temperature. 